\title{
DETERMINANT CORPORATE TURNAROUND
}

\author{
Animah \\ Fakultas Ekonomi Dan Bisnis Universitas Mataram \\ animahmtr@yahoo.co.id
}

\begin{abstract}
The objective of this study is to analyze the factors that affect corporate turnaround when a company experiencing financial distress. Idependent variables used in this research are severity company, company size, expenses retrenchment, CEO turnover and dependent variable corporate turnaround. The research sample consisted of 12 financial sector companies listed on the Indonesia Stock Exchange during 2008-2010. Data were collected by using purposive sampling method.

The hypothesis testing based on multiple linear regression analysis. The result of date analysis indicated that the variableof severity company, company size, expenses retrenchmentand CEO turnover simultaneously affect the corporate turnaround. Partially, only variablecompany of size was found to have influence on corporate turnaround. Meanwhile, severity company, expenses retrenchment and CEO turnover were found to have no influence on the corporate turnaround. $R$ Square value shows that the ability of the four independent variables in explaining the corporate turnaround success was $31.6 \%$ and the varians of corporate turnaround success $68.4 \%$ were explain by other factors that explain.

Keywords: financial distress, corporate turnaround, leverage, company size, the size of the audit committee, CEO turnover
\end{abstract}

\section{PENDAHULUAN}

Masalah perekonomian dunia yang berimbas pada perekonomian Indonesia pernah dialami pada tahun 2008. Dimana pada saat itu kondisi ekonomi Indonesia diuji karena adanya krisis keuangan global yang terjadi.Salah satu perusahaan yang terkena dampak dari krisis tersebut adalah perusahaan sektor perbankan.Akibat krisis tersebut memaksa perbankan Indonesia harus menghadapinya dengan berat, yang mengakibatkan persaingan pun semakin ketat dalam merebut pasar dalam negeri.Dimana perbankan pada saat itu semakin hati-hati memberikan kredit dengan likuiditas yang terbatas dan suku bunga yang mahal. Hal ini mau tidak mau harus dilakukan perbankan untuk dapat bertahan dalam menghadapi krisis ekonomi tersebut. 
Disamping penyebab krisis yang dialami perbankan diatas, menurut Sudarsono (2009) krisis tersebut juga menyebabkan perbankan mengalami penurunan nilai aktiva produktif (earning assets) dalam bentuk kredit dan surat berharga yang dibeli, penurunan kecukupan modal (CAR), serta gagal bayar bunga kredit. Hal ini mengakibatkan perusahan-perusahaan perbankan mengalami kesulitan keuangan (financial distress) akibat rendahnya tingkat kesehatan yang dialami perusahaan.Karena kesulitan keuangan (financial distress) tersebut itulah maka memicu perusahaan-perusahaan perbankan untuk bangkit dan memperoleh keberhasilan keluar dari masalah keuangaan(turnaround) mereka.

Strategi turnaround diterapkan oleh sebuah bank atau perusahaan dari sektor lainnya bukan semata-mata karena ia tengah ditimpa krisis, tetapi memang ada kondisi kritis yang harus diperbaiki. Situasi krisis bisa muncul dalam skala besar maupun dalam skala kecil.Krisis besar biasanya timbul karena kondisi perekonomian yang memang sedang tertimpa masalah. Dalam hal ini semua bank akan mengalami tahap resesi, kolaps bahkan sampai bangkrut. Sedangkan krisis dalam skala yang lebih kecil bisa muncul karena percikan masalah yang berasal dari lingkup internal perusahaan.Biasanya berasal dari kesalahan, kecurangan dan kejahatan yang dibuat oleh pegawainya sendiri.Meskipun dalam skala kecil, krisis semacam ini dapat mendorong perusahaan ke dalam jurang kebangkrutan.

Situasi kritis yang dialami perbankan baik itu dalam skala besar maupun kecil mampu menyebabkan perbankan mengalami krisis keuangan yang berdampak pada penurunan kinerja keuangan perusahaan (financial distress). Financial distressadalah keadaan dimana perusahaan berada dalam keadaan tidak sehat atau kritis.Platt dan Platt (2002) mendefinisikan financial distresssebagai tahap penurunan kondisi keuangan yang terjadi sebelum terjadinya kebangkrutan ataupun likuidasi.Karena terjadinya distress itulah perbankan berusaha untuk memperoleh turnaround agar tidak terjadi distress yang berkepanjangan yang nantinya mampu menyebabkan perbankan mengalami kebangkrutan. Turnaround merupakan pembalikan arah perusahaan dari penurunan kinerja menjadi peningkatan kinerja keuangan perusahaan (Schendel, et al., 1976).

Terjadinya penurunan dalam kinerja perusahaan setelah adanya financial distress yang terjadi dapat mengalami keberlanjutan yang diakibatkan oleh kinerja manajemen perusahaan yang buruk, Untuk itu strategi manajemen yang tepat dalam perusahaan sangat diperlukan sehingga financial distress dapat diatasi. Pihak manajemen yang tanggap mendeteksi financial distress lebih awal, kemudian bertindak aktif menganalisa penyebab financial distress dan menerapkan strategi 
turnaroundyang tepat, akan jauh lebih dapat mengendalikan kondisi tersebut (Schuppe, 2005).

Banyak penelitian telah dilakukan untuk meneliti faktor-faktor yang membuat suatu perusahaan dapat keluar dari financial distress yang dialaminya. Dalam penelitian ini faktor-faktor yang digunakan adalah severitas, ukuran perusahaan, expensess retrenchment, dan CEO turnover.

Penelitian Robin dan Pearce (1992) menemukan bahwa severitas berpengaruh terhadap keberhasilan turnaround.Semakin besar tingkat penurunan kinerja, maka semakin sulit bagi perusahaan untuk mencapai turnaround, begitu juga sebaliknya.Namun dalam penelitian yang dilakukan oleh Makgeta (2010) menunjukkan hasil bahwa tingkat severitas tidak mempengaruhi keberhasilan turnaround.

Ukuran perusahaan merupakan karakteristik perusahaan yang turut mempengaruhi hasil turnaround (Haveman,1993, Singh dan Lumsden, 1990dalam Francis dan Desai, 2005). Ukuran perusahaan dapat dilihat dari total asetnya, omset penjualan perusahaan ataupun jumlah karyawan yang dimiliki (Francis dan Desai, 2005).Besar kecilnya ukuran perusahaan menunjukkan seberapa besar perusahaan tersebut dapat keluar dari keadaan distress yang dialami untuk dapat memperoleh turnaround.Perusahaan besar biasanya dapat keluar dari zona distress mereka dengan cepat, sedangkan perusahaan kecil harus melakukan usaha yang lebih keras lagi untuk keluar dari distress mereka.

Penelitian Chandrawati (2008) menunjukkan bahwa ukuran perusahaan berpengaruh positif terhadap keberhasilan turnaround. Ukuran perusahaan secara konsisten memiliki tanda koefisien regresi yang positif dengan nilai probabilitas (Sig.) yang lebih kecil dari $5 \%$. Hal ini berarti perusahaan yang lebih besar lebih mempunyai kemampuan untuk reorganisasi karena lebih mudah mendapatkan tambahan dana dari investor dan kreditor karena mempunyai profil yang lebih tinggi, modal dan aset yang lebih besar, ketika menghadapi financial distress dan kemungkinan yang lebih besar untuk bertahan. Namun pada penelitian Makgeta (2010) menyebutkan bahwa ukuran perusahaan tidak berpengaruh terhadap keberhasilan turnaround.

Kemudian untukexpenses retrenchment, manajemen harus mengambil peran aktif dalam mengatasi penurunan kinerja perusahaan (Barker dan Mone, 1994). Dalam mengatasi distress hal yang harus dilakukan perusahaan adalah melakukan efisiensi.Seperti melakukan pengurangan atas segala macam pembiayaan dan beban. Hal ini dapat membantu perusahaan ketika mengalami distress sembari memulihkan keadaan perusahaan menuju ke turnaround. 
Penelitian Elidawati et al., (2015) menunjukkan bahwa expenses retrenchment secara parsial tidak terbukti berpengaruh terhadap keberhasilan turnaround. Hal ini dikarenakan hanya terdapat sekitar $10 \%$ dari jumlah keseluruhan perusahaan yang menjadi sampel yang berhasil mencapai turnaround yang melakukan expenses retrenchment. Bertentangan dengan penelitian Marbun dan Situmeang (2014) yang menyatakan bahwaexpenses retrenchmentberpengaruh terhadap keberhasilan turnaround dengan tingkat signifikan sebesar 5\%. Kemampuan perusahaan dalam mengelola efisiensi perusahaannya dengan menekan beban-beban yang tidak berguna untuk operasi perusahaan dapat mendukung kemampuan perusahaan yang dalam keadaan financial distress untuk memperoleh corporate turnaround.

CEO turnover didefinisikan sebagai suatu peristiwa ketika CEO dari suatu organisasi digantikan dengan individu lain (Bruton et al., 2003). Suatu perusahaan mengganti CEOnya tidak hanya dengan alasan bahwa masa jabatan telah habis, namun juga dapat dikarenakan perusahaan tersebut mengalami masalah yang diakibatkan oleh CEO mereka, ataupun karena perusahaan tersebut mengalami financial distress, sehingga perlu adanya perbaikan dari CEO yang baru.

Penelitian Candrawati (2008) dan Astari (2010) yang menunjukkan hasil bahwa CEO turnovertidak berpengaruh terhadap keberhasilan turnaround. Hal ini berarti bahwa perusahaan yang mengalami turnaround dapat berasal dari perusahaan yang mengalami pergantian CEO maupun yang tidak mengalami pergantian CEO. Bertentangan dengan penelitian Marbun dan Situmeang (2014) bahwa CEO turnover berpengaruh terhadap keberhasilan turnaround.

Berdasarkan pemaparan tersebut di atas, maka permasalahan yang diteliti dalam penelitian ini adalah apakah severitas perusahaan berpengaruh positif terhadap corporate turnaround, apakah ukuran perusahaan berpengaruh positif terhadap corporate turnaround, apakah expenses retrenchment berpengaruh positif terhadap corporate turnaround, apakah CEO turnoverberpengaruh positif terhadap corporate turnaround.

Teori Agency (teori keagenan) merupakan teori yang menjelaskan hubungan antara pemilik perusahaan dengan manajemen perusahaan.Hubungan yang terjadi antara pemilik perusahaan dengan manajemen perusahaan tersebut merupakan suatu kontrak dan didalamnya terdapat pemisahan antara kepemilikan dan manajer.Dalam perekonomian moderen, manajemen dan pengendalian perusahaan semakin terpisah dari kepemilikan. Manager bertanggung jawab terhadap pemilik. Tujuan dari system pemisahan tersebut adalah untuk menciptakan keefisiensian dan keefektifan dengan mempekerjakan agen-agen profesional dalam mengelola 
perusahaan.Penguasaan kendali perusahaan dipegang oleh agen, sehingga agen dituntut untuk selalu transparan dalam melaksanakan kendali perusahaan.

Penelitian ini dilakukan untuk menguji pengaruh severitas, ukuran perusahaan, expenses retrenchment, dan CEO turnoverterhadap keberhasilan turnaround ketika mengalami financial distress.

Gambar 1 : Kerangka Konseptual Penelitian

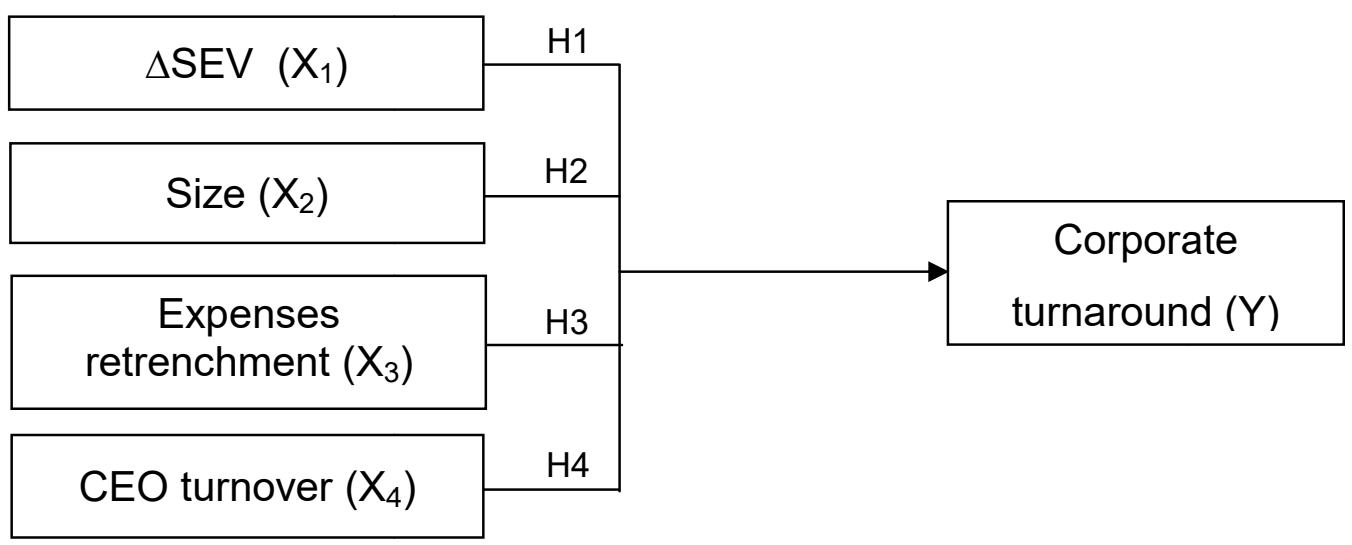

\section{Pengaruh Severitas Terhadap Keberhasilan Turnaround}

Pada dasarnya perusahaan yang mengalami penurunan keuangan secara drastis dan bahkan hampir bangkrut akan lebih berusaha keras untuk segera mengambil tindakan yang penting untuk mencapai kondisi turnaround dibandingkan dengan perusahaan yang memiliki kecenderungan tingkat penurunan keuangan yang tidak terlalu parah.Perusahaan dengan tingkat penurunan kinerja (distress) yang tidak terlalu parah dapat menerapkan berbagai strategi seperti mengembangkan pemasaran dan promosi penjualan atau bergerak ke dalam segmen pasar yang lain (Lohrke dan Bedeian, 1998), sedangkan perusahaan yang memiliki tingkat kecenderungan distress yang lebih parah memiliki keterbatasan dalam melakukan pemanfaatan sumber daya (Robbin dan Pearce, 1992).

Semakin besar tingkat kerugian yang akan dialami oleh perusahaan (severitas) maka semakin sulit perusahaan dalam melakukan turnaround. Sebaliknya semakin kecil tingkat severitas yang dialami oleh perusahaan maka akan semakin cepat perusahaan dalam memperoleh turnaround.

Dalam penelitian Robbin dan Pearce (1992) menyatakan bahwa severitas berpengaruh terhadap keberhasilan turnaround. Penelitian Candrawati (2008) menyatakan bahwa severitas yang tinggi mengindikasikan profitabilitas perusahaan akan mengalami recovery lebih besar. Sebaliknya, perusahaan dengan severitas yang rendah mengindikasikan profitabilitas 
recovery semakin kecil.Penelitian Elidawati et al. (2015) menyatakan bahwa severitas berpengaruh terhadap keberhasilan turnaround.

Berdasarkan uraian tersebut, maka hipotesis dalam penelitian ini adalah :

$\mathrm{H}_{1}$ :Severitas berpengaruh positif terhadap keberhasilan turnaround.

\section{Pengaruh Ukuran Perusahaan Terhadap Keberhasilan Turnarond}

Pada dasarnya, perusahaan yang berukuran kecil akan lebih mampu untuk dapat beradaptasi dengan cepat terhadap perubahan lingkungan dikarenakan perusahaan yang berukuran kecil memiliki resiko yang kecil pula dibandingkan dengan perusahaan yang berukuran besar (Pant, 1991 dalam Smith \& Graves, 2005). Namun, dilihat dari pengalaman terhadap pasar, perusahaan yang lebih besar memiliki kesiapan yang lebih matang dalam menghadapi masalah keuangan, dikarenakan pula perusahaan yang berukuran besar memiliki modal dan aset yang lebih banyak sehingga dapat dijadikan jaminan untuk melakukan peminjaman ketika perusahaan mengalami financial distress dibanding dengan perusahaan yang berukuran kecil (White, 1983 dalam Routledge \& Gadenne, 2000).

Ukuran perusahaan memainkan peranan yang penting yang dapat mempengaruhi keberhasilan turnaround, karena ukuran perusahaan merupakan sumber daya yang nyata (Francis dan Desai, 2005).Perusahaan besar pada dasarnya memiliki prosedur internal yang berbelit-belit, terutama dikarenakan banyaknya anak perusahaan yang dimiliki sehingga hubungan kerjanya lebih beragam yang berakibat pada kemampuan merespon situasi yang lebih lambat (Hambrick dan D'Aveni, 1988 dalam Francis dan Desai, 2005). Sedangkan perusahaan kecil mempunyai struktur yang tidak terlalu kompleks dan dapat merespon perubahan secara lebih cepat (Meyer dan Zucker, 1989 dalam Francis dan Desai, 2005). Menurut Bruton et. al., (2003) perusahaan-perusahaan di Asia Tenggara yang mengalami penurunan kinerja dengan ukuran perusahaan yang lebih kecil akan lebih dapat berhasil dalam proses turnaround daripada perusahaan berukuran besar.

Perusahaan yang berukuran kecil akan lebih dapat memperoleh turnaround dengan cepat dibandingkan dengan perusahaan yang berukuran besar. Penelitian Marbun dan Situmeang (2014) menyatakan bahwa ukuran perusahaan berpengaruh terhadap keberhasilan turnaround. Serta penelitian Candrawati (2008) juga menunjukkan bahwa ukuran perusahaan berpengaruh terhadap keberhasilan turnaround.

Sehinggaberdasarkan uraian tersebut maka hipotesis dalam penelitian ini adalah:

$\mathrm{H}_{2}$ : Ukuran perusahaan berpengaruh positif terhadap keberhasilan turnaround. 


\section{Pengaruh Expenses Retrenchment Terhadap Keberhasilan Turnaround}

Peningkatan efisiensi dengan menggunakanexpenses retrenchment ketika perusahaan mengalami financial distress akan mempengaruhi keberhasilan turnaround. Semakin baik strategiexpenses retrenchment yang digunakan oleh perusahaan maka keberhasilan turnaroundakan dapat diperoleh, namun sebaliknya apabila pemanfaatan strategi efisiensi dengan expenses retrenchment tidak dapat dimanfaatkan dengan baik oleh perusahaan maka turnaround akan sulit untuk diperoleh oleh perusahaan.

Penelitian Marbun dan Situmeang (2014) menyatakan bahwa expenses retrenchment berpengaruh terhadap keberhasilan turnaround.

Sehingga hipotesis dalam penelitian ini adalah :

$\mathrm{H}_{3}$ : Expenses retrenchment berpengaruh positif terhadap keberhasilan turnaround.

\section{Pengaruh CEO TurnoverTerhadap Keberhasilan Turnaround}

Suatu keputusan yang diambil untuk keberlangsungan perusahaan terutama ketika perusahaan mengalami penurunan kinerja dilakukan oleh pimpinan perusahaan itu sendiri. Sehingga CEO memiliki peranan yang sangat penting terhadap pengambilan keputusan perusahaan untuk keberlangsungan operasional perusahaan tersebut. Adanya perubahan pimpinan dikarenakan oleh berbagai faktor antara lain dikarenakan memang masa jabatan habis, atau dikarenakan pimpinan tersebut terlibat masalah yang besar sehingga harus digantikan, atau dapat pula pergantian dilakukan karena perusahaan yang dipimpin oleh pimpinan sebelumnya tidak mengalami kemajuan (diam ditempat) atau mengalami financial distress sehingga harus digantikan dengan alasan dikarenakan dengan adanya pergantian CEO tersebut perusahaan dapat lebih berkembang ataupun dapat keluar dari zona distress untuk memperoleh turnaround apabila CEO diganti dengan alasan pada masa jabatannya perusahaan mengalami distress.

Penelitian Marbun dan Situmeang (2014) menyatakan bahwa CEO turnover berpengaruh terhadap keberhasilan turnaround.

Sehingga hipotesis dalam penelitian ini adalah :

$\mathrm{H}_{4}$ : CEO turnover berpengaruh positif terhadap keberhasilan turnaround

\section{METODE PENELITIAN}

Jenis penelitian yang digunakan dalam penelitian ini adalah penelitian asosiatif. Populasi yang digunakan dalam penelitian ini adalah seluruh sektor perbankan konvensional yang telah terdaftar di Bursa Efek Indonesia (BEI). 
Kemudian untuk penentuan sampel akan dilakukan dengan menggunakan metode purposive sampling

Teknik pengumpulan data yang digunakan dalam penelitian ini adalah dokumentasi yaitu menganalisis data dari dokumen-dokumen yang diperoleh (Sujarweni, 2014:75). Dimana data tersebut berupa laporan keuangan perusahaan yang telah terdaftar di Bursa Efek Indonesia yaitu www.idx.co.id yang mana data perusahaan yang terdaftar di Bursa Efek tersebut diperoleh di Saham OK yaitu di www.sahamok.com

Jenis data yang digunakan dalam penelitian ini adalah data dengan sumber data dalam penelitian ini menggunakan data sekunder. Variabel dependen atau terikat dalam penelitian ini adalah corporate turnaround, sedangkan variabel independen dalam penelitian ini adalah severity $\left(X_{1}\right)$, ukuran perusahaan (size) $\left(\mathrm{X}_{2}\right)$, expenses retrenchment $\left(\mathrm{X}_{3}\right)$, dan CEO turnover $\left(\mathrm{X}_{4}\right)$.

\section{Definisi Konseptual dan Operasional Variabel Corporate Turnaround(Y)}

Turnaround didefinisikan sebagai pembalikan arah perusahaan dari penurunan kinerja (Schendel et al., 1976).Menurut Supardi dan Mastuti (2003) turnaround dilakukan ketika manajemen mengalami kegagalan dalam membesarkan perusahaan sehingga prospek perusahaan menjadi tidak jelas dan mengalami krisis yang berkepanjangan sehingga pemilik dan manajemen berusaha keras memutar arah organisasi.Mengacu pada penelitian Marbun dan Situmeang (2014) corporate turnaround diukur dengan menggunakan dummy (kategorik) dimana 0 untuk perusahaan yang gagal melakukan corporate turnaround dan 1 untuk perusahaan yang berhasil melakukan corporate turnaround.Dimana perusahaan yang gagal dalam melakukan corporate turnaround adalah perusahaan yang memiliki ROI dibawah tingkat suku bunga bebas risiko. Sedangkan perusahaan yang dinyatakan berhasil melakukan corporate turnaroundadalah perusahaan yang memiliki ROI kembali diatas tingkat suku bunga bebas risiko. Rumus ROI menurut Tampubolon (2005:39) dihitung sebagai berikut :

$$
\text { ROI }=\frac{\text { Laba bersih setelah pajak }}{\text { Investasi }}
$$

\section{Severitas $\left(\mathbf{X}_{1}\right)$}

Severitaspada kondisi kesulitan keuangan akan ditentukan oleh komponen ukuran kesulitan keuangan dan mengidentifikasi sumber utama atas kesulitan keuangan tersebut. Arah dan perluasan atas perubahan severitasmenyediakan dukungan lebih lanjut untuk kemungkinan 
turnaround(Smith dan Graves, 2005). Untuk mengukur severitasmenggunakan metode analisis Altman Z-score yang mengacu pada penelitian Smith dan Graves (2005), Robbin dan Pearce (1992), Candrawati (2005), dan Marbun dan Situmeang (2014).

$$
Z=\underset{(\mathrm{MVE} / \mathrm{BVD})}{6,56(\mathrm{WC} / \mathrm{TA})}+3,26(\mathrm{RE} / \mathrm{TA})+6,72(\mathrm{EBIT} / \mathrm{TA})+1,05
$$

Keterangan :

(WC/ TA)

(RE/ TA)

$=$ asset lancar - hutang lancar $/$ total asset

(EBIT/ TA)

(MVE/ BVD)

= laba ditahan / total asset

$Z>2,9$

= laba bersih sebelum pajak / total asset

$=$ ekuitas / total hutang

$1,22<Z<2,9$

= perusahaan berada di zona aman

$Z<1,22$

= perusahaan berada di zona abu-abu

= perusahaan berada di zona distress

\section{Ukuran Perusahaan $\left(\mathbf{X}_{2}\right)$}

Menurut Francis dan Desai (2005), ukuran perusahaan merupakan gambaran dari besar kecilnya suatu perusahaan yang dapat dilihat dari total asset, omset penjualan ataupun jumlah karyawan suatu perusahaan.Ukuran perusahaan memainkan peran yang penting yang berpengaruh positif terhadap keberhasilan turnaround karena ukuran perusahaan merupakan sumber daya yang nyata. Untuk mengukur ukuran perusahaan menggunakan logaritma natural yang mengacu pada penelitian Francis dan Desai (2005).

$$
L n \text { size }=L n \text { total asset }
$$

\section{Expenses Retrenchment $\left(\mathrm{X}_{3}\right)$}

Menurut Francis dan Desai (2005), expenses retrenchment dioperasionalisasikan sebagai pengurangan bersih pada biaya termasuk harga pokok penjualan, biaya penjualan dan biaya umum dan administrasi di dalam garis waktu penentuan keberhasilan turnaround perusahaan. Untuk mengukur expenses retrenchment menggunakan rumus yang mengacu pada penelitian Smith dan Graves (2005).

Expenses retrenchment $=\left(\mathrm{TEXP}_{\mathrm{t}}-\mathrm{TEXP}_{\mathrm{t}-1}\right) / \mathrm{TEXP}_{\mathrm{t}-1}$

Keterangan :

$\mathrm{TEXP}_{\mathrm{t}}=$ total biaya tahun $\mathrm{t}$

$\mathrm{TEXP}_{\mathrm{t}-1}=$ total biaya sebelum tahun $\mathrm{t}(\mathrm{t}-1)$

\section{CEO Turnover $\left(\mathrm{X}_{\mathbf{4}}\right)$}

Dimana pergantian CEO dilakukan karena masa jabatan telah habis, atau dikarenakan bahwa CEO terdahulu memiliki masalah sehingga harus 
diganti, atau juga karena pada saat CEO terdahulu memimpin perusahaan tidak mengalami perkembangan atau karena perusahaan yang dipimpin mengalami financial distress sehingga dibutuhkan CEO baru yang dapat merubah perusahaan menjadi jauh lebih baik lagi. Untuk mengukur CEO turnover menggunakan dummy (kategori), dimana 0 jika perusahaan tidak melakukan pergantian CEO dan 1 jika perusahaan melakukan pergantian CEO.

\section{Uji Hipotesis}

Pengujian hipotesis dilakukan dengan menggunakan metode analisis regresi logistik karena memiliki satu variabel dependen (terikat) yang non metrix (nominal) serta memiliki variabel independen (bebas) lebih dari satu. Teknik analisis regresi logistik ini tidak memerlukan uji normalitas dan uji asumsi klasik pada variabel bebasnya (Ghozali, 2005 : 211)

Karakteristik dari variabel dependen yang bersifat dichotomous dalam penelitian ini mendukung digunakannya analisis regresi logistik yaitu keberhasilan turnaround atau kegagalan turnaround(Chandrawati, 2005).Model regresi logistik yang digunakan adalah untuk menguji apakah variabel-variabel independen yang digunakan dapat mempengaruhi keberhasilan turnaround. berikut :

Adapun model regresi logistik yang diajukan adalah sebagai

$$
\operatorname{Ln} \frac{P}{1-P}=b_{0}+b_{1} \Delta S E V+b_{2} \text { SIZE }+b_{3} \text { EXRET }+b_{4} \text { CEO }
$$

Dimana :

$\mathrm{P}$

$\mathrm{B}_{0} \quad=$ konstanta

$\mathrm{B}_{1}-\mathrm{b}_{5} \quad=$ koefisien variabel bebas

Keberhasilan turnaround (jika 1 maka berhasil melakukan turnaround, jika 0 maka tidak berhasil melakukan turnaround)

$\triangle \mathrm{SEV} \quad=\Delta$ tingkat kesehatan perusahaan (besarnya kerugian)

SIZE $\quad=$ ukuran perusahaan

EXRET = pengurangan biaya

CEO =CEO turnover ( 1 jika ada pergantian, 0 jika tidak ada pergantian) 
Analisis pengujian model regresi logistik memperhatikan :

1. Menilai model regresi

Dalam menilai model regresi logistik dapat dilihat dari pengujian Hosmar and Lemeshow's goodnest of fit.Pengujian ini dilakukan untuk menilai model yang dihipotesiskan agar data empiris cocok atau sesuai dengan model. Jika nilai statistik Hosmer dan Lemeshow's goodness of fit test sama dengan atau kurang dari 0,05, maka hipotesis nol ditolak. Sedangkan jika nilainya lebih besar dari 0,05, maka hipotesis nol tidak dapat ditolak, artinya mampu memprediksi nilai observasinya atau cocok dengan data.

$\mathrm{H}_{0}=$ model yang dihipotesiskan fit dengan data

$\mathrm{H}_{1}=$ model yang dihipotesiskan tidak fit dengan data

2. Menilai keseluruhan model (overall model fit)

Untuk menilai keseluruhan model, ditunjukkan dengan log likelihood value (nilai -2LL) yaitu dengan cara membandingkan antara nilai -2LL pada awal (block number $=0$ ) dimana model hanya memasukkan konstanta dengan nilai $-2 \mathrm{LL}$ pada saat block number $=1$, dimana model mamasukkan konstanta dan variabel bebas. Apabila nilai -2LL block number $=0>$ nilai $-2 \mathrm{LL}$ block number $=1$, maka menunjukkan model regresi yang baik. Log likelihood pada regresi logistik mirip dengan pengertian "sum of square error" pada model regresi sehingga penurunan log likelihood menunjukkan model regresi semakin baik.

3. Menguji koefisien regresi

Pengujian koefisien regresi dilakukan untuk menguji seberapa jauh semua variabel bebas yang dimasukkan dalam model mempunyai pengaruh terhadap variabel terikat.Hasil pengujian didapat dari program SPSS berupa tampilan table variabel in the equation. Dari table tersebut didapat nilai koefisien, nilai wald statistics, dan signifikansi.

Untuk menentukan penerimaan atau penolakan $\mathrm{H}_{0}$ dapat ditentukan dengan menggunakan wald statistic dan nilai probabilitas (sig) dengan cara nilai wald statistic dibandingkan dengan chi-square table. Sedangkan nilai probabilitas (sig) dibandingkan dengan tingkat signifikansi (a) $5 \%$ dengan kriteria :

a. $\mathrm{H}_{0}$ tidak dapat ditolak apabila walchitung <chi-square table dan nilai Asymptotic significance > tingkat signifikan (a). Hal ini berarti $\mathrm{H}$ nol ditolak atau hipotesis yang menyatakan variabel bebas berpengaruh terhadap variabel terikat ditolak.

b. $\mathrm{H}_{1}$ ditolak apabila walchitung >chi-square table dan nilai asymptotic significance < tingkat signifikan (a). Hal ini berarti $\mathrm{H}$ alternative 
diterima atau hipotesis yang menyatakan variabel bebas berpengaruh terhadap variabel terikat diterima.

\section{HASIL DAN PEMBAHASAN}

Pengujian hipotesis dalam penelitian ini menggunakan model regresi logistik untuk menguji pengaruh severitas, ukuran perusahaan, expenses retrenchment dan CEO turnover terhadap turnaround perusahaan. Data yang digunakan untuk menganalisis variabel dalam penelitian ini adalah data dari laporan keuangan perusahaan perbankan dari tahun 2007-2010.

Analisis pertama yang dilakukan yaitu dengan menilai kelayakan model regresi dan goodness of fit test yang diukur dengan Chi-square pada pengujian Hosmer and Lemeshow's dan diperoleh nilai sebesar 4.681. probabilitas signifikansi menunjukkan nilai 0.699 , dimana nilai signifikansi dari Chi-square ini lebih besar dari 0.05 sehingga $\mathrm{H}_{0}$ tidak dapat ditolak (diterima) yang berarti bahwa model regresi ini mampu memprediksi nilai observasi data atau dengan kata lain cocok dengan data sehingga pengujian hipotesis dapat dilakukan.

Tabel 1

Hasil Uji Hosmer and Lemeshow's

\begin{tabular}{|c|r|r|c|}
\hline Step & Chi-square & df & Sig. \\
\hline 1 & 4.681 & & 0.699 \\
\hline
\end{tabular}

Sumber : data sekunder diolah (lampiran 8)

Selanjutnya adalah menilai keseluruhan model (overall model fit) yang dilihat dari nilai -2 Log Likelihood (-2 LL) pada tabel berikut :

Tabel 2

Hasil Uji Overall Model Fit Model Analisis

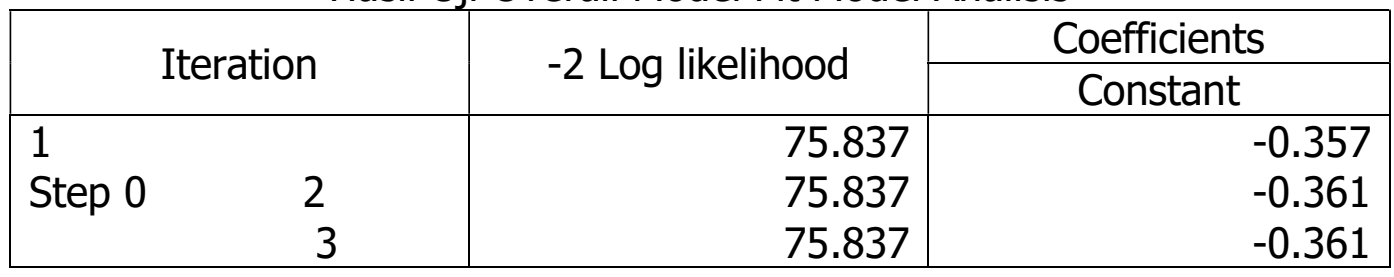

\begin{tabular}{|c|r|c|c|}
\hline Step & -2 Log likelihood & $\begin{array}{c}\text { Cox \& Snell R } \\
\text { Square }\end{array}$ & $\begin{array}{c}\text { Nagelkerke R } \\
\text { Square }\end{array}$ \\
\hline 1 & 60.903 & 0.234 & 0.316 \\
\hline
\end{tabular}

Sumber : data sekunder diolah (lapiran 8)

Pada tabel 2 menunjukkan bahwa nila -2 LL pada awal (block number $=0$, dimana model hanya memasukkan konstanta dengan nilai 
sebesar 75.837, sedangkan nilai -2 LL pada saat block number $=1$, dimana model memasukkan konstanta dan variabel bebas turun menjadi 60.903. Hal ini berarti bahwa $-2 \mathrm{LL}$ pada block number $=0$ lebih besar dari pada nilai $-2 \mathrm{LL}$ pada block number $=1$ sehingga model regresi ini dapat dikatakan layak atau semakin baik. Nilai Nagelkerke R Square sebesar 0.316 lebih besar dari nilai Cox \& Snell R Square yang menunjukkan bahwa kemampuan keempat variabel bebas dalam menjelaskan varians keberhasilan turnaround adalah sebesar $31.6 \%$ dan $68.4 \%$ adalah faktor lain yang menjelaskan varians keberhasilan turnaround.

Untuk menunjukkan kekuatan prediksi dari model regresi untuk memprediksi perusahaan melakukan turnaround ketika mengalami financial distress adalah sebagai berikut :

Tabel 3

Tabel Klasifikasi Model Analisis

\begin{tabular}{|c|c|c|c|}
\hline \multirow{3}{*}{ Observed } & \multicolumn{3}{|c|}{ Predicted } \\
\hline & \multicolumn{2}{|c|}{ Turnaround } & \multirow[b]{2}{*}{$\begin{array}{l}\text { Percentage } \\
\text { correct }\end{array}$} \\
\hline & $\begin{array}{c}\text { Gagal } \\
\text { turnaround }\end{array}$ & $\begin{array}{l}\text { Berhasil } \\
\text { turnaround }\end{array}$ & \\
\hline $\begin{array}{l}\text { Gagal turnaround } \\
\text { Turnaround }\end{array}$ & 26 & 7 & 78.8 \\
\hline Berhasil turnaround & 8 & 15 & 65.2 \\
\hline Overall Percentage & & & 73.2 \\
\hline
\end{tabular}

Sumber : data sekunder diolah (lampiran 8)

Tabel 3kekuatan prediksi dari model regresi untuk memprediksi kemungkinan perusahaan melakukan turnaround ketika mengalami financial distress adalah sebesar $73.2 \%$. Hal ini menunjukkan bahwa ketepatan model ini secara keseluruhan sebesar $73.2 \%$.

Kemudian analisis selanjutnya adalah melakukan pengujian koefisien regresi untuk menguji seberapa jauh semua variabel bebas yang dimasukkan dalam model mempunyai pengaruh terhadap variabel terikat. Koefisien regresi ini dapat ditentukan dengan menggunakan Wald Statistik dan nilai probabilitas (Sig.) seperti yang terlihat pada tabel 4.

Dari model tersebut dapat dinyatakan pada tampilan output variabel in the equation model analisis sebagai berikut :

$$
\operatorname{Ln} \frac{P}{1-P}=4.905-1.179 \Delta s e v-0.228 \text { size }-0.706 \text { exret }-0.615 \text { ceo }
$$


Tabel 4

Hasil Uji Koefisien Regresi Logistik Model Analisis

\begin{tabular}{|c|c|c|c|c|c|c|}
\hline & $B$ & S.E. & Wald & $\mathrm{df}$ & Sig. & $\operatorname{Exp}(B)$ \\
\hline Sev & -1.179 & 1.055 & 1.248 & 1 & 0.264 & 0.308 \\
\hline Size & -0.228 & 0.80 & 8.099 & 1 & 0.004 & 0.796 \\
\hline Step 1 Exret & -0.706 & 0.929 & 0.577 & 1 & 0.447 & 0.494 \\
\hline Ceo & -0.615 & 0.740 & 0.691 & 1 & 0.406 & 0.541 \\
\hline Constant & 4.905 & 1.771 & 7.670 & 1 & 0.006 & 134.935 \\
\hline
\end{tabular}

Sumber : data sekunder yang diolah (lampiran 8)

Dari persamaan regresi logistik tersebut dapat diketahui bahwa hanya variabel size (ukuran perusahaan) yang berpengaruh signifikan terhadap keberhasilan turnaround, yang artinya bahwa perusahaan yang berukuran kecil akan mampu lebih cepat memperoleh turnaround dari pada perusahaan yang berukuran besar. Hal ini dibuktikan dengan nilai Sig. pada variabel size (ukuran perusahaan) $<5 \%$ dan nilai wald statistik yang dimiliki variabel size (ukuran perusahaan) >chi-square tabel. Dilihat dari nilai konstanta yang negative yaitu sebesar -0.228 yang dimiliki oleh variabel ukuran perusahaan menunjukkan bahwa ukuran perusahaan berpengaruh negative terhadap keberhasilan turnaround. Sedangkan variabel severitas, expenses retrenchment dan CEO turnover dinyatakan tidak berpengaruh terhadap keberhasilan turnaround. Hal ini dibuktikan dengan nilai Sig. pada variabel severitas, expenses retrenchment dan CEO turnover > 5\% dan nilai wald statistik yang dimiliki oleh variabel severitas, expenses retrenchment dan CEO turnover <chi-square tabel, serta nilai konstanta yang dimiliki oleh variabel severitas, expenses retrenchment dan CEO turnover adalah negative.

\section{Hasil Pengujian $\mathrm{H}_{1}$}

Hasil uji regresi logistik untuk model analisis menunjukkan bahwa variabel severitas memiliki koefisien regresi yang negative dengan nilai probabilitas (Sig.) yang lebih besar dari 0.05 (a), yang aritnya bahwa severitas tidak berpengaruh terhadap keberhasilan turnaround.

Hasil dari temuan ini menunjukkan ketidaksesuaian tanda dengan hipotesis, yang berarti bahwa besar kecilnya tingkat kerugian yang dialami perusahaan tidak mempengaruhi berhasil tidaknya perusahaan dalam melakukan turnaround. Variabel severitas diukur dengan $z$-score dari analisis altman yang mengandung unsur rasio keuangan sebagai berikut :

$$
Z=6,56(\mathrm{WC} / \mathrm{TA})+3,26(\mathrm{RE} / \mathrm{TA})+6,72(\mathrm{EBIT} / \mathrm{TA})+1,05(\mathrm{MVE} / \mathrm{BVD})
$$


$\Delta \mathrm{SEV}=\mathrm{Z}_{\mathrm{t}}-\mathrm{Z}_{\mathrm{t}-1}$

Rasio WC/TA merupakan rasio likuiditas yang menunjukkan perbandingan modal kerja (aktiva lancar - hutang lancar) dengan total aktiva yang mengukur kemampuan likuiditas modal kerja perusahaan dengan aktiva, rasio RE/TA dan EBIT/TA merupakan rasio profitabilitas yang menunjukkan sejauh mana aset yang digunakan menghasilkan profit, dan rasio MVE/BVD merupakan perbandingan nilai pasar ekuitas perusahaan dan total hutang perusahaan.

Hasil penelitian ini tidak mendukung penelitian yang dilakukan olehRobbin dan Pearch (1992), Candrawati (2008) serta penelitian Elidawati et al. (2015) yang menyatakan bahwa severitas berpengaruh terhadap keberhasilan turnaround, namun hasil penelitian ini mendukung penelitian Makgeta (2010) dan penelitian Marbun dan Situmeang (2014) yang menyatakan bahwa severitas tidak berpengaruh terhadap keberhasilan turnaround. Hal ini dapat diakibatkan oleh kondisi bisnis yang terjadi di Indonesia pada tahun-tahun terjadinya krisis yaitu disekitar tahun pengamatan, dimana pada saat itu pemerintah memutuskan untuk membantu beberapa bank yang terkena dampak dari terjadinya krisis global tersebutterutama bank-bank milik pemerintah sendiri dengan memberikan bantuan dana. Hal tersebut membuat kecendrungan tanpa menilai tingkat keparahan kondisi keuangan perusahaan yang mengalami financial distress. Sehingga dapat ditarik kesimpulan bahwa severitas tidak berpengaruh terhadap keberhasilan turnaround.

\section{Hasil Pengujian $\mathrm{H}_{2}$}

Hasil uji regresi logistik untuk model analisis menunjukkan bahwa variabel ukuran perusahaan memiliki tanda koefisien regresi yang negative dengan nilai probabilitas (Sig.) yang lebih kecil dari 0.05 (a), yang artinya bahwa ukuran perusahaan berpengaruh negative dan signifikan terhadap keberhasilan turnaround.

Hasil dari penelitian ini menunjukkan ketidaksesuaian dengan hipotesis yang menyatakan bahwa ukuran perusahaan berpengaruh positif terhadap keberhasilan turnaround. Perusahaan berukuran kecil biasanya memiliki peluang yang lebih besar untuk dapat keluar dari distress yang dialami dan memperoleh turnaround dari pada perusahaan yang berukuran besar.

Variabel ukuran perusahaan dalam penelitian ini diukur dengan log natural dari total aset. Hal ini sekaligus mendukung penelitian Candrawati (2008) dan penelitian dari Marbun dan Situmeang (2014) yang menyatakan bahwa ukuran perusahaan berpengaruh signifikan terhadap keberhasilan turnaround. Hal ini dikarenakan bahwa ukuran besar kecilnya perusahaan 
memainkan peranan yang penting yang dapat mempengaruhi keberhasilan turnaround, karena ukuran perusahaan merupakan sumber daya yang nyata. Hal ini dilihat dari banyaknya anak perusahaan yang dimiliki. Jika dilihat dari hal tersebut, ketika perusahaan berukuran kecil mengalami financial distress maka lingkup fokus mereka akan lebih kecil atau sedikit, sehingga mereka akan lebih cepat mendeteksi dan menemukan masalah yang menyebabkan perusahaan mengalami distress dan lebih cepat mengambil tindakan untuk mengatasi masalah distress tersebut yang kemudian cepat pula perusahaan memperoleh turnaround. Namun, pada perusahaan yang berukuran besar, dimana perusahaan memiliki banyak anak perusahaan, yang kemudian ketika perusahaan mengalami financial distress maka tidak hanya induk perusahaan saja yang mengalami dampaknya melainkan seluruh anak perusahaan yang dimiliki juga akan memperoleh dampak dari terjadinya distress yang dialami. Dengan banyaknya anak perusahaan yang dimiliki maka akan sulit menemukan penyebab dari masalah financial distress, hal ini dikarenakan lingkup perusahaan yang lebih luas sehinga akan sulit untuk menemukan fokus masalah dan akan membutuhkan waktu yang lebih lama untuk mengatasi masalah distress, sehingga untuk memperoleh turnaround pun perusahaan yang berukuran besar akan sulit memperolehnya.

\section{Hasil Pengujian $\mathrm{H}_{3}$}

Hasil uji regresi logistik untuk model analisis menunjukkan bahwa variabel expenses retrenchment memiliki tanda koefisien regresi yang negative dengan nilai probabilitas (Sig.) yang lebih besar dari 0.05 (a), yang artinya expenses retrenchment tidak berpengaruh terhadap keberhasilan turnaround.

Hasil dari penelitian ini menunjukkan ketidaksesuaian dengan hipotesis, yang berarti besar kecilnya pengurangan biaya yang dilakukan tidak mempengaruhi berhasil tidaknya perusahaan melakukan turnaround. Expenses retrenchment dalam penelitian ini diproksikan dengan pengurangan total aset dari total aset tahun sebelumnya. Hasil penelitian ini tidak mendukung penelitian Marbun dan Situmeang (2014) yang menyatakan bahwa expenses retrenchment berpengaruh terhadap keberhasilan turnaround. Melainkan mendukung penelitian Elidawati et al. (2015) yang menyatakan bahwa expenses retrenchment tidak berpengaruh terhadap keberhasilan turnaround. Secara teori pengurangan biaya baik itu besar maupun kecil belum tentu dapat membantu perusahaan untuk keluar dari distress mereka dan mencapai turnaround. Sehingga dapat dinyatakan bahwa expenses retrenchment tidak berpengaruh terhadap keberhasilan turnaround. 


\section{Hasil Pengujian $\mathrm{H}_{\mathbf{4}}$}

Hasil uji regresi logistik untuk model analisis menunjukkan bahwa variabel CEO turnover memiliki koefisien regresi negative dan menunjukkan nilai probabilitas (Sign.) lebih besar dari 0.05 (a), yang menunjukkan bahwa CEO turnover tidak berpengaruh terhadap keberhasilan turnaround.

Hasil dari penelitian ini menunjukkan ketidaksesuaian dengan hipotesis, yang berarti bahwa CEO turnover tidak berpengaruh terhadap keberhasilan turnaround. Variabel CEO turnover ini merupakan variabel dummy yang dilihat dari adanya perubahan CEO dari tahun ke tahun selama periode penelitian. Hasil penelitian ini tidak mendukung penelitian Candrawati (2008) yang menyatakan bahwa CEO turnover berpengaruh terhadap keberhasilan turnaround. Melainkan mendukung penelitian Astari (2010) yang menyatakan bahwa CEO turnover tidak berpengaruh terhadap keberhasilan turnaround. Pergantian CEO pada suatu perusahaan tidak hanyak dilakukan ketika perusahaan mengalami financial distress, melainkan pula dapat dilakukan antara lain ketika masa jabatan dari CEO tersebut telah habis, perusahaan tidak mengalami kemajuan selama masa jabatan CEO tersebut atau CEO tidak lagi dianggap mampu menguntungkan perusahaan, cara kerja CEO tidak cocok dengan karyawan atau CEO terlalu mengontrol karyawannya, atau bahwakan karena adanya masalah yang dilakukan oleh CEO tersebut seperti melakukan penggelapan dana perusahaan. Dengan kata lain adanya pergantian CEO maupun tidak adanya pergantian CEO tidak menjamin perusahaan tersebut dapat memperoleh turnaround ketika perusahaan mengalami distress. Sehingga dapat disimpulkan bahwa CEO turnover tidak berpengaruh terhadap keberhasilan turnaround.

\section{SIMPULAN}

Penelitian ini bertujuan untuk mengetahui keberhasilan turnaround pada perusahaan perbankan yang terdaftar di Bursa Efek Indonesia dari tahun 2007-2010 dengan menggunakan variabel-variabel yang diprediksi mempengaruhi turnaround perusahaan yaitu severitas, ukuran perusahaan, expenses retrenchmendan CEO turnover. Hasil dari penelitian ini dapat disimpulkan sebagai berikut :

1. Severitas secara statistik tidak berpengaruh terhadap keberhasilan turnaround dengan nilai koefisien regresi yang negative dan nilai Sig. lebih besar dari $5 \%$. Sehingga hipotesis untuk severitas berpengaruh positif terhadap keberhasilan turnaround ditolak.

2. Ukuran perusahaan secara statistik berpengaruh negative dan signifikan terhadap keberhasilan turnaround dengan nilai koefisien regresi yang 
Animah: Determinan Corporate Turnaround

negative dan nilai Sig. lebih kecil dari 5\%. Sehingga hipotesis untuk ukuran perusahaan berpengaruh positif terhadap keberhasilan turnaround ditolak.

3. Expenses retrenchment secara statistik tidak berpengaruh terhadap keberhasilan turnaround dengan nilai koefisien regresi yang negative dan nilai Sig. lebih besar dari 5\%. Sehingga hipotesis untuk expenses retrenchment berpengaruh positif terhadap keberhasilan turnaround ditolak.

4. CEO turnover secara statistik tidak berpengaruh terhadap keberhasilan turnaround dengan nilai koefisien regeresi yang negative dan nilai Sig. lebih besar dari $5 \%$. Sehingga hipotesis untuk CEO turnover berpengaruh positif terhadap keberhasilan turnaround ditolak.

Penelitian ini memiliki beberapa keterbatasan yaitu : dilakukan hanya pada sektor keuangan yaitu perusahaan perbankan konvensional yang terdaftar di Bursa Efek Indonesia tahun 2007-2010 dengan jumlah sampel sebanyak 14 perusahaan dengan jumlah data sebanyak 56 data laporan keuangan.Penelitian ini hanya meneliti perusahaan yang mengalami financial distress dengan melihat dari nilai arus kas operasi yang negative.

Adapun saran yang diberikan sebagai pertimbangan untuk meningkatkan kualitas dari penelitian selanjutnya yaitu dapat dilakukan pada perusahaan sektor non keuangan lain baik itu jasa, manufaktur maupun dagang. Sehingga sampel untuk penelitian lebih banyak dan hasil yang beragam sehingga dapat diperbandingkan dengan penelitian sebelumnya dan alat analisisnya dapat dapat menggunakan analisis diskriminan pada perusahaan yang mengalami financial distress untuk memperoleh turnaround perusahaan.

\section{REFERENSI}

Altman, E. I., and Hotchkiss, E. 2006.Corporate Financial Distress and Bankcrupty.John Wiley and Son, Inc. New York.

Arogyaswamy, Kamala, Vincent L. Barker lii, and Masoud Yasai-Ardekani. 1995. Firm Turnarounds : An Intrgrative Two-Stage Model. Journal of Management Studies, Vol. 15, Issue 5, pp.395-405.

Astari, Nidya Alyssa. 2010. Analisis Faktor-Faktor yang Mempengaruhi Keberhasilan Turnaround Pada Perusahaan yang Mengalami Financial Distress.

Augustine, Yvonne dan Robert Kristaung.2013. Metode Penelitian Bisnis dan Akuntansi.Jakarta : Dian Rakyat. 
Barker III, V. L., and I. M. Duhaime. 1997. Strategic Change in the Turnaround Process : Theory and Empirical Evidence. Strategic Management Journal, 18 (1), 13-38.

Barker III, V. L., and Mone, M.A. 1994.Retrenchment : Cause of Turnaround or Consequence of Decline. Strategic Management Journal,Vol. 15, Issue 5, pp.395-405.

Baroroh, Ali. 2013. Analisis Multivariat dan Time Series dengan SPSS 21.Jakarta : Elex Media Komputindo.

Bibeault, D. 1982. Corporate Turnaround : How Managers Turn Losers Into Winners. Mc Graw Hill. New York.

Brutton, Garry D., David Ahlstrom, and Johnny C. C. Wan. 2003. Turnaround in East Asian Firms : Evidence from FECC.

Candrawati, Anna. 2008. Analisis Faktor-Faktor yang Mempengaruhi Keberhasilan Turnaround Pada Perusahaan yang Mengalami Financial Distress (Studi Pada Perusahaan Non Keuangan yang Terdaftar di Bursa Efek Jakarta Tahun 2000-2005).Tesis. Universitas Diponegoro. Semarang.

Casey, Cornelius J., Victor E. McGee, and Clyde P. Stickney. 1986. Discriminating Between Reorganized and Liquidated Firms in Turnaround Efforts. Academy of Management Executive, vol. 6 (3).

Damodaran, A. 1997.Corporate Finance: Theory and Practice. John Wiley. New York.

David, Fred R. 2002. Manajemen Strategis : Konsep, Edisi Ketujuh. Jakarta : PT. Prenhallindo.

Elidawati, Azhar Maksum, dan M. Lian Dalimunthe. 2015. Faktor-Faktor yang Mempengaruhi Keberhasilan Turnaround Pada Perusahaan yang Mengalami Financial Distress di Bursa Efek Indonesia. Fakultas Ekonomi dan Bisnis. Universitas Sumatera Utara.

Emery, Dauglas R., and John D. Dinnerty. 2004. Corporate Financial Management, Second Editor. Pearson Education, Inc.

Fauzi, Muhammad. 2011. Analisis Kinerja (Performance) Perbankan dan Pengaruhnya Terhadap Kesulitan Keuangan (Financial Distress) Perbankan di Indonesia. Fakultas Ekonomi. Universitas Sebelas Maret. Surakarta.

Francis, John D and Desai, Ashay B. 2005.Situational and Organizational Determinants of Turnaround.Management Decision 43.

Ghozali, I. 2005. Aplikasi Analisis Multivariate dengan Program SPSS.Semarang : Badan Penerbit Universitas Diponegoro.

Hofer, C.W. 1980. Turnaround Strategies. Journal of Business Strategy, Vol. 1 , Issue 1, pp. 19-31. 
Jensen, M. 1989. Active Investors, LOBs and Privatisation of Bangkrupcy.Journal of Applied Corporate Finance, Vol. 2, Issue 1, pp. 35-44.

Latan, Hengky dan Selva Temalagi. 2013. Analisis Multivariate Teknik dan Aplikasi Menggunakan Program IBM SPSS 20. Bandung : Alfabeta.

Lestari, Rizki Dwi dan Ni Nyoman Alit Triani. 2013. Determinan Keberhasilan Turnaorund Pada Perusahaan yang Mengalami Financial Distress. Fakultas Ekonomi. Surabaya. Jurnal Ilmu Manajemen, Vol. 1 (4).

Lohrke, F. T., and A. G. Bedeian. 1998. Managerial Responses to Declining Performance : Turnaround Investment Strategies and Critical Contingencies. Advances in Applied Business Strategy 5 : 3-20.

Makgeta, Malose. 2010. Turnaround Determinants of Distressed Firms Funded by the Industrial Development Corporation. Dissertation. University of Pretoria.

Marbun. Hendra Agustinus H., dan Chandra Situmeang. 2014. Financial Distrss dan Corporate Turnaround. Universitas Negeri Medan.

Ofek, E. 1993. Capital Structure and Firm Response to Poor Performance : An Empirical Analysis. Journal of Financial Economic, Vol. 19, Issue 1, pp.3-30.

Robbins, D.K., and J.A.II.Pearch. 1992. Turnaround : Retrenchment and Recovery. Strategic Management Journal 13 (4).

Routledge, J., and D. Gadenne. 2000. Financial Distress, Reorganization and Corporate Performance. Accounting and Finance, 40.

Sarianti. 2016. Peringkat Corporate Social Responsibility Disclosure Sebagai Strategi Managerial Entrenchment Pada Perusahaan Pertambangan yang Financial Distress. Fakultas Ekonomi dan Bisnis. Universitas Mataram.

Schendel, D.E., and G.R. Patton. 1976. Corporate Stagnation and Turnaround. Journal of Economic and Business, Vol. 28, Issue 3, pp. 236-241.

Schendel, D.E., G. R. Patton, and J. Riggs. 1976. Corporate Turnaround Strategics : A Study of Profit Decline and Recovery. Journal of General Management, Vol. 3, Issue 3, pp. 3-11.

Schuppe, Walter P. 2005. Leading A Turnaround. The Secured Lender.

Siregar, Riszky Indriyani dan Syarief Fauzie.2015. Analisis Manfaat Rasio Keuangan Dalam Memprediksi Financial Distress Pada Perbankan. Universitas Sumatera Utara.

Smith, M and C. Graves.2005. Corporate Turnaround and Financial Distress. Managerial Auditing Journal 20 (3). 
Sudarsono, Heri. 2009. Dampak Krisis Keuangan Global Terhadap Perbankan di Indonesia : Perbandingan antara Bank Konvensional dan Bank Syariah. Jurnal Ekonomi Islam, Vol. III (1).

Sujarweni, V.W. 2014. Metodologi Penelitian. Yogyakarta : PUSTAKABARUPRESS

Supardi, Sri Mastuti. 2003. Validitas Penggunaan Z-score Altman Untuk Menilai Kebangkrutan Pada Perusahaan Perbankan yang Go Publik di Bursa Efek Jakarta.

Tampubolon, Manahan. 2005. Manajemen Keuangan, Edisi pertama. Jakarta : Ghalia Indonesia.

Pearce, J.A., and K. Robbins. 1993. Toward Improved Theory and Research on Business Turnaround. Journal of Management, 19 (3).

Platt, Harlan D. and Majori B. Platt. 2002. Predicting Corporate Financial Distress : Reflections on Choice-Based Sample Bias. Journal of Economic and Finance 26 (2).

Weiss, I.A. 1990. Priority of Claims and Ex Post Re-Contracting in Bankruptcy.Journal of Financial Economic, Vol. 27, Issue 2, pp. 285317. 